\title{
Experimental Study of Flexural Behaviour of Reinforced Baked Clay Beams under Impact Loading
}

\author{
Nawab Ali Lakho, Muhammad Auchar Zardari* \\ Department of Civil Engineering, Quaid-e-Awam University of Engineering Science and Technology, \\ Nawabshah, Pakistan \\ Email: "muhammad.auchar@quest.edu.pk
}

Received 31 May 2016; accepted 20 June 2016; published 23 June 2016

Copyright (C) 2016 by authors and Scientific Research Publishing Inc.

This work is licensed under the Creative Commons Attribution International License (CC BY). http://creativecommons.org/licenses/by/4.0/

c) (i) Open Access

\section{Abstract}

This paper presents behaviour of Reinforced Baked Clay (RBC) beams under drop weight impact loading. The beams were made of two different grades of baked clay with cube crushing strength of $20 \mathrm{MPa}$ and $30 \mathrm{MPa}$, respectively. The RBC beams were subjected to repeated drop weight loading by a hammer of weight equal to that of the specimen being tested. The results showed that the impact resistance of the RBC beams was governed by the compressive strength of the baked clay. Failure of grade 20 beams occurred due to irregular cracks and the beams of grade 30 failed by opening of a single crack at mid span. It was observed that the beams of grade 30 had sustained about 1.5 times more number of impacts until steel in tension zone yielded and failed completely after necking.

\section{Keywords}

Baked Clay, Impact Loading, Cracks, Deflection, Compressive Strength, Reinforcement

\section{Introduction}

Clay is being used, since ancient time, in unbaked and baked states for the construction of houses [1]-[3]. Sun baked and fired bricks are being used for the erection of buildings since the dawn of civilizations in various parts of the world, e.g. in Greece, Mesopotamia and Indus valley [4]-[6]. The buildings constructed of fired bricks are still in existence after hundreds of years. The bricks cast and fired in same manner today have average compressive strength of about $12 \mathrm{MPa}$ [7]. If the clay bricks are compacted mechanically at higher degree of density and fired at standard temperature, they may give higher degree of compressive strength.

${ }^{*}$ Corresponding author. 
Structural members such as beams, columns and slabs may be subjected to dynamic loads besides compressive, shear, tensile and flexural loads. The dynamic loads on buildings are in general due to extreme wind and seismic vibrations [8]. To determine the effect of such impact loads on a structural member, various types of impact and impulsive tests are conducted such as: 1) falling mass, 2) air ballast, 3) spring loads, 4) deformation controlled impact and 5) pendulum loading [9].

Currently, due to terrorist activities, highly explosive attacks are common everywhere [10]-[12]. Thus, it is imperative to design buildings which may remain safe in such dynamic loading conditions. This necessitates to investigate the impact resistance of other low cost materials such as baked clay.

Reinforced Baked Clay (RBC) is a light weight, heat and fire resistant material having compressive strength equal to that of normal weight concrete [13]. Previous studies suggest that RBC is a potential construction material as a replacement of reinforced cement concrete in order to erect low cost houses [14]-[16]. However, the behaviour of RBC under impact load is not yet conducted. The object of this study is to investigate behaviour of RBC beams under impact loading. For this purpose, guidelines for testing reinforced concrete beams under impact loads were followed to specify the size of specimen, weight of hammer and the drop height, see, e.g. [17][20].

\section{Materials and Methods}

\subsection{Casting of Beams}

Local clay was excavated in vicinity of Nawabshah city at a depth of $1200 \mathrm{~mm}$ in order to decrease possibility of mixing of aggregates and organic matter in the quarry. The excavated clay was initially dried and then pulverized. The clay was mixed with pit sand by weight in a ratio of 70:30. This proportion of clay and pit sand was adopted from another study [13] which suggested that addition of pit sand was helpful in increasing compressive strength and minimizing shrinkage and cracks of clay beams. The mixture was put in a pan mixer and $22 \%$ of water was added. This much quantity of water was required in order to achieve workability and proper bond between the layers of clay beams. The mixing was carried out for 15 minutes. The clay and sand mixture was put in layers in steel mould (Figure 1) of the Mechanized System [21] to cast and compact the clay beams. Two batches of clay beams were cast. Each batch consisted of three beams. During casting process, the clay beams were compacted with the help of wooden plunger (Figure 2). First batch of beams was compacted at a pressure of $1.94 \mathrm{MPa}$ and the other batch was compacted at $6 \mathrm{MPa}$. Both batches of clay beams were dried in shade and then baked in a kiln at a temperature of $1000^{\circ} \mathrm{C}$. Cubes of size $150 \mathrm{~mm}$ were cut from the baked clay beams and were tested in Universal Testing Machine.

Average compressive strength of the cubes was found to be $20 \mathrm{MPa}$, and $30 \mathrm{MPa}$, for both batches, respectively. Beams of $150 \mathrm{~mm} \times 150 \mathrm{~mm} \times 500 \mathrm{~mm}$ were cut from both batches. The baked clay beams were under

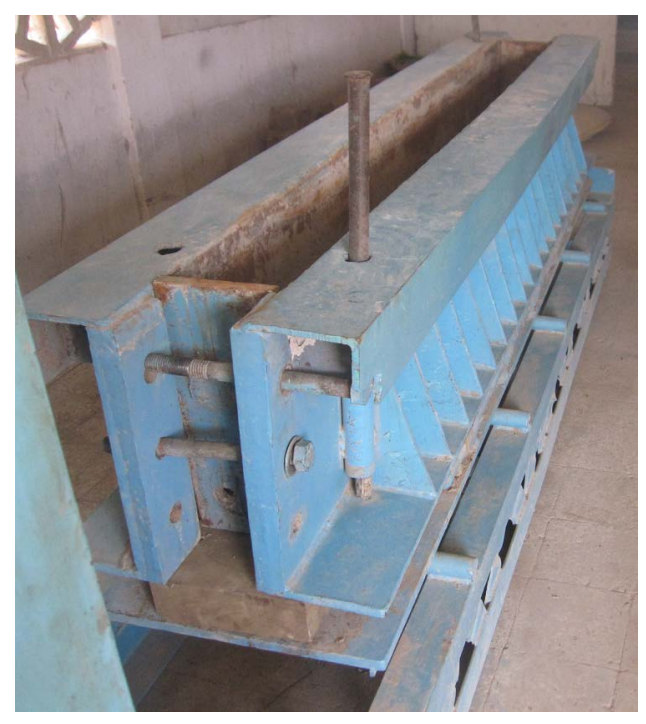

Figure 1. Mould utilized for casting of clay beams. 
reinforced with a single $6 \mathrm{~mm}$ steel bar in both compression and tension (Figure 3). The RBC beams were tested in drop weight impact loading machine designed for this purpose.

\subsection{Drop Weight Impact Load Testing Machine}

A drop weight impact testing machine was designed and fabricated to test RBC beams (Figure 4). This testing machine is composed of: 1) a pair of truss section, 2) a pair of double vertical post channel sections, 3) four tension stiffening steel plates, 4) two $2130 \mathrm{~mm}$ long steel pipes, 5) hammer and tup assembly.

The truss frames are welded to each other so that they form a stiff frame for supporting the beam. This frame is $2300 \mathrm{~mm}$ long and $450 \mathrm{~mm}$ high. A vertical frame composed of two pairs of $2130 \mathrm{~mm}$ long channel section, were welded to each other. The hammer assembly is composed of a steel box. The box is so designed that two $20 \mathrm{~kg}$ standard weights can be accommodated. A $150 \mathrm{~mm}$ long semicircular tup was welded with the hammer

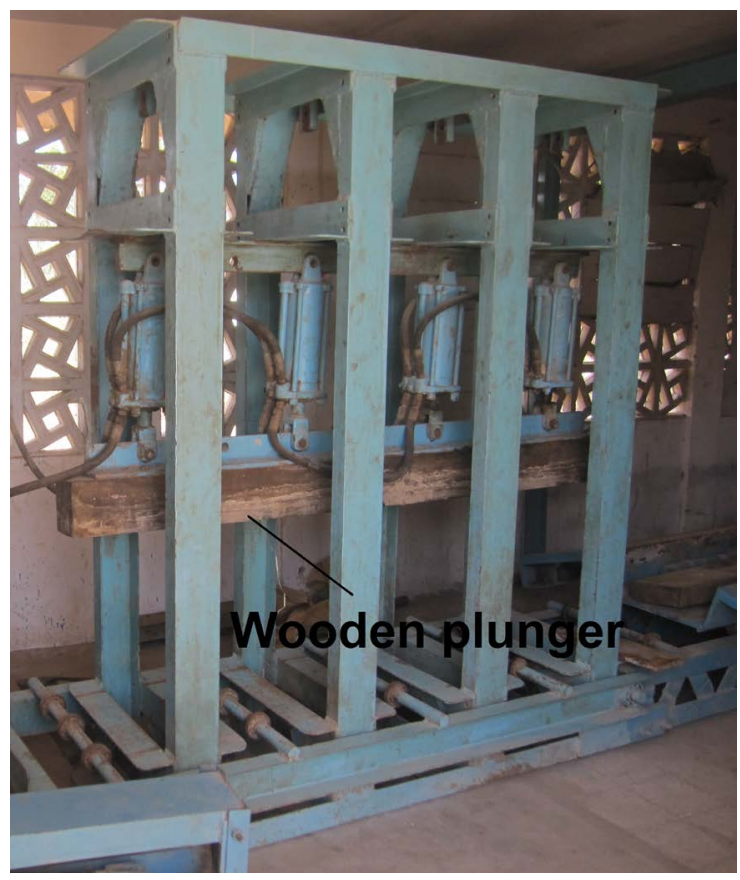

Figure 2. Wooden plunger used to compress clay beams in mechanized system.

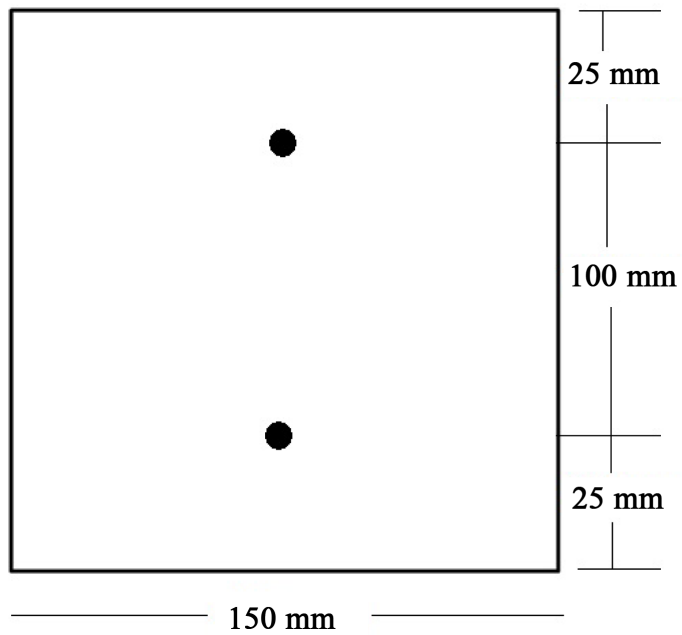

Figure 3. Cross section of reinforced baked clay beam. 
assembly which can smoothly slide between vertical posts. Two $152 \mathrm{~mm}$ steel pipes were welded vertically at their ends in the system so that the hammer slides along those pipes and has only small allowance of lateral movement of only $2 \mathrm{~mm}$. The hammer can be raised manually up to a height of more than $1500 \mathrm{~mm}$.

\section{Results and Discussion}

\section{Deflection Behaviour under Impact Loading}

The RBC beams of grade 20 got cracked on application of first impact applied at mid span. On application of further impacts, a number of irregular cracks of different sizes occurred and the beams failed completely (Figure 5). The RBC beams of grade 30 got cracked at the impact of first blow of hammer at mid span in tension zone. On application of further impacts, the beams failed by developing shear plug below the point of impact in tension zone and yielding of a reinforcing bar (Figure 6).

It is interesting to investigate in detail the effect of compressive strength (i.e. grade 20, and grade 30) of baked clay on deflection behaviour by keeping the area of reinforcement as constant. For this purpose, the deflection response of the beams of grade 20 was compared with those of grade 30. Figure 7 presents comparison of impact response of the beams of grade 20 and 30. It can be observed that grade 30 beams showed 1.5 times more

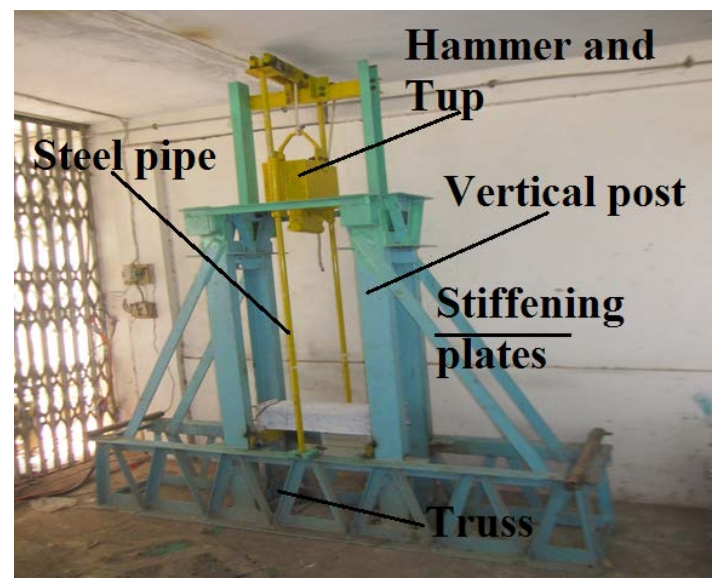

Figure 4. Drop weight impact testing machine.

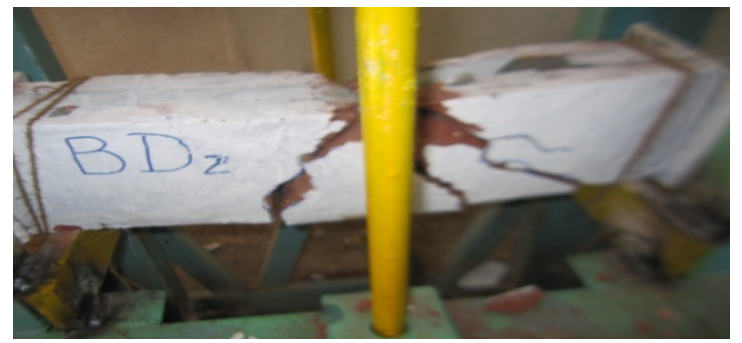

Figure 5. Failure behaviour of reinforced baked clay beam of grade 20 under impact load.

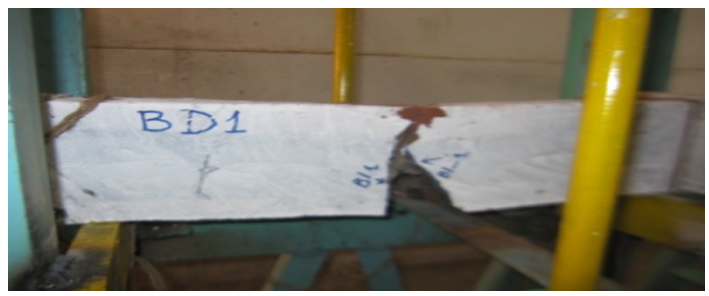

Figure 6. Failure behaviour of reinforced baked clay beam of grade 30 under impact load. 


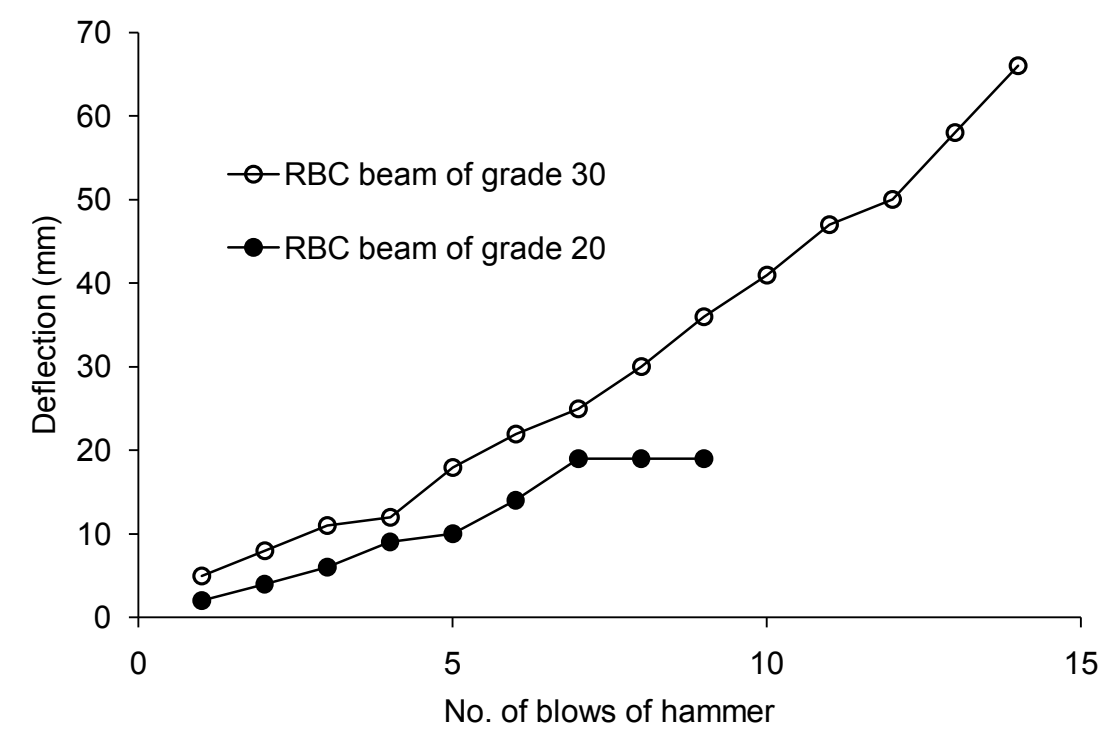

Figure 7. Comparison of impact resistance of reinforced baked clay beams of grade 20 and 30 .

impact resistance as compared to the grade 20 beams. This is because, 1) the beam of grade 30 failed due to yielding of a steel bar followed by crushing of baked clay, and 2) the beams of grade 20 failed due to crushing of baked clay material. This behaviour of the RBC beams is consistent with that of RCC beams, see e.g. Khan [22].

\section{Conclusions}

In this study, effect of cube crushing strength on impact resistance and deflection behaviour of Reinforced Baked Clay (RBC) beams under drop weight impact loading were investigated. The experimental programme has led to the following conclusions:

1) Cube crushing strength of $\mathrm{RBC}$ is directly related to resistance to impact loading; the larger the cube crushing strength is, the higher the resistance to impact loading of RBC beams is.

2) The RBC beams of grade 20 showed global failure by developing a number of irregular cracks both in the compression and tension zones.

3) The RBC beams of grade 30 exhibited a single crack in tension zone below the point of impact and failed by yielding of a steel bar in tension zone.

\section{Acknowledgements}

The authors would like to thank Quaid-e-Awam University of Engineering Science and Technology Nawabshah, for providing access to the Structural Engineering Laboratory to conduct the tests mentioned in this study.

\section{References}

[1] Mathur, V.K. (2006) Composite Materials from Local Resources. Construction and Building Materials, 20, $470-477$. http://dx.doi.org/10.1016/j.conbuildmat.2005.01.031

[2] Adelabu, O.S. (2012) Documentation, Application and Utilisation of Clay Minerals in Kaduna State (Nigeria). INTECH Open Access Publisher, Rijeka.

[3] Adam, J.P. (2005) Roman Building: Materials and Techniques. Routledge, London.

[4] Baizerman, M. (2012) Dawn and Sunset: Insight into the Mystery of the Early Mesopotamian Civilization. Strategic Book Publishing, Houston.

[5] Gates, C. (2011) Ancient Cities: The Archaeology of Urban Life in the Ancient Near East and Egypt, Greece and Rome. Routledge, London.

[6] Mcintosh, J.R. (2005) Ancient Mesopotamia: New Perspectives. ABC-CLIO, Inc., California.

[7] Khoso, S., Wagan, F.H., Khan, J.S., Bhatti, N.K. and Ansari, A.A. (2014) Qualitative Analysis of Baked Clay Bricks 
Available in Larkana Region, Pakistan. Architecture - Civil Engineering-Environment, 7, 41-50.

[8] Struck, W. and Voggenreiter, W. (1975) Examples of Impact and Impulsive Loading in the Field of Civil Engineering. Materials and Structures, 8, 81-87. http://dx.doi.org/10.1007/bf02476326

[9] Skov, K. and Olesen, S.Ø. (1975) Impact Resistance of Reinforced and Prestressed Concrete Members. Materials and Structures, 8, 116-125. http://dx.doi.org/10.1007/bf02476329

[10] Horváth, A. and Csaba, Z. (2012) On the Vulnerability and Reliability of Towns and Cities. In: Csapó, T. and Balogh, A., Eds., Development of the Settlement Network in the Central European Countries, Springer, Berlin Heidelberg, 299-312. http://dx.doi.org/10.1007/978-3-642-20314-5 22

[11] Kumar, C. (2012) Challenges of Global Terrorism-Strategies, Dimensions and Response: In Search of a Perspective. International Affairs and Global Strategy, 3, 7-20.

[12] Harmon, C.C. (2013) Terrorism Today. Volume 7, Routledge, London.

[13] Ansari, A.A. (2008) Experimental Study of the Behaviour of Pre-Perforated Post-Reinforced Baked Clay Panels of Beams. PhD Thesis, Department of Civil Engineering, Quaid-e-Awam University of Engineering Science \& Technology, Nawabshah.

[14] Ansari, A.A., Bhatti, N.K. and Bhutto, A. (2013) Suitability of Pre-Perforated Post-Reinforced Baked Clay Beam Panels for Low Cost Housing. American Journal of Civil Engineering, 1, 6-15. http://dx.doi.org/10.11648/j.ajce.20130101.12

[15] Ansari, A.A. and Lakho, N.A. (2013) Determination of Structural Properties of Baked Clay as Replacement of RCC. International Journal of Emerging Technology and Advanced Engineering, 3, 17-25.

[16] Lakho, N.A. and Zardari, M.A. (2016) Comparison of Compressive and Tensile Strength of Baked Clay with Those of Normal Concrete. Engineering, 8, 301-307. http://dx.doi.org/10.4236/eng.2016.86027

[17] Abbas, A.A., Pullen, A.D. and Cotsovos, D.M. (2010) Structural Response of RC Wide Beams under Low-Rate and Impact Loading. Magazine of Concrete Research, 62, 723-740. http://dx.doi.org/10.1680/macr.2010.62.10.723

[18] Smith, L.G. (1945) Actual and Estimated Impact Resistance of Some Reinforced-Concrete Units Failing in Bending. Journal of the ICE, 23, 163-179. http://dx.doi.org/10.1680/ijoti.1945.14106

[19] Appleby-Thomas, G.J. and Hazell, P.J. (2012) The Impact of Structural Composite Materials. Part 2: Hypervelocity Impact and Shock. The Journal of Strain Analysis for Engineering Design, 47, 406-418. http://dx.doi.org/10.1177/0309324712448299

[20] Fan, J., Guan, Z.W. and Cantwell, W.J. (2011) Numerical Modelling of Perforation Failure in Fibre Metal Laminates Subjected to Low Velocity Impact Loading. Composite Structures, 93, 2430-2436. http://dx.doi.org/10.1016/j.compstruct.2011.04.008

[21] Lakho, N.A., Zardari, M.A., Memon, M. and Saand, A. (2015) Design and Fabrication of a Mechanized System for Casting and Compacting Laboratory Size Clay Beams. Scientia Iranica, International Journal of Science and Technology, 22, 2046-2051.

[22] Khan, I.K. (2014) Performance of Reinforced Concrete Beam under Point Impact Loading. American International Journal of Research in Science, Technology, Engineering \& Mathematics, 6, 146-150.

\section{Submit or recommend next manuscript to SCIRP and we will provide best service for you:}

Accepting pre-submission inquiries through Email, Facebook, Linkedin, Twitter, etc

A wide selection of journals (inclusive of 9 subjects, more than 200 journals)

Providing a 24-hour high-quality service

User-friendly online submission system

Fair and swift peer-review system

Efficient typesetting and proofreading procedure

Display of the result of downloads and visits, as well as the number of cited articles

Maximum dissemination of your research work

Submit your manuscript at: http://papersubmission.scirp.org/ 